\title{
Simple Correlation and Multiple Regression among Leaf and Smoke Characteristics of Burley Tobaccos*
}

by

T. C. Tso

Tobacco Laboratory, Beltsville Agricultural Researd Center, Agricultural Researd Service, U.S. Department of Agriculture, Beltsville, Maryland, U.S.A.

J. F. Chaplin

Oxford Tobacco Station, Agricultural Researd Service, U.S. Department of Agriculture, Oxford, North Carolina, U.S.A.

and

\section{J. D. Adams and D. Hoffmann}

Naylor Dana Institute for Disease Prevention, American Health Foundation, Valhalla, New York, U.S.A.

In a recent report we discussed simple correlations and multiple regressions among leaf dharacteristics, smoke components and biological responses of bright tobaccos (12). In this report, we deal with the leaf and smoke characteristics of Burley tobaccos. Bright and Burley tobacco types differ considerably in genetic make-up, cultural and curing practices; these differences are reflected in the diemical and physical properties of the leaf (11). This present study is important in establishing the relationship among precursors from the leaf to products in the smoke of Burley tobaccos. Burley tobaccos are a major component of blended cigarettes, and many other smoking products. These correlations can serve as indicators for the chemical nature of the leaf precursors of smoke constituents and can suggest model studies. However, absolute correlations are best established by studying the fate of ${ }^{14} \mathrm{C}$-labelled precursors (1).

\section{MATERIALS AND METHODS}

Burley tobacco (Nicotiana tabacum L.) cultivars, including Burley 21, Kentudky (Ky) 14, Kentucky (Ky) 12, and a low-alkaloid breeding line (LA Burley 21), were selected for this study on the basis of their alkaloid levels. Total alkaloid content in Burley 21 was $4.20 \%$; in $\mathrm{Ky} 14,3.71 \%$; in $\mathrm{Ky} 12,3.66 \%$; and in LA Burley

\footnotetext{
- Presented at the 7th International Tobacco Scientific Congress (Coresta) held in Manila, The Philippines, in 1980.

Receired: 9th April 1981 - accepted: 10th Novenber 1981.
}

$21,0.86 \%$. The plants were grown in the field in a randomized complete block design with four replications, in 1976 at Lexington, Kentudky. Normal cultural and air-curing practices for Burley tobacco were followed, and the plants were hand-suckered. After curing, the leaves were classified according to eight stalk posicions, each of which contained two or more leaves. Position one represents the lowest leaves and position eight the top leaves. The midribs were removed from the leaves, and a sample of leaf laminae from each stalk position of each plot was ground to pass through a $1 \mathrm{~mm}$ mesh screen. The samples from each replicate were combined for chemical analysis. The remainder of all leaf samples for each cultivar from four replications according to the assigned stalk position were used to manufacture experimental cigarettes. These cigarettes were non-filter, $85 \mathrm{~mm}$ in length, $25 \mathrm{~mm}$ in circumference, leaf cut was 32 per ind, and the cigarette paper burned at a rate of $30 \mathrm{~cm} / \mathrm{min}$. These specifications are similar to those of the U.S. Tobacco Working Group (TWG) experimental series (3). Several selected characteristics of the experimental cigarettes are listed in Table 1 . Leaves were analyzed in a cooperative program involving many industrial and public research laboratories ${ }^{+}$. Each laboratory used its own established methods (12). Cigarette

\footnotetext{
+ The following laboratories collaborated in conducting leaf analyses: Beltsville Tobacco Laboratory, U.S.D.A., Bejesville, Md.; Kentucky University Tobacco Laboratory, Lexington, Ky.; Lorillard Tobacco Research Laboratory, Greensboro, N.C.; Oxford Tobacco Laboratoty, U.S.D.A., Oxford, N.C.; Philip Mortis Research Laboratory, Ridimond, Va.; and R. J. Reynolds Research Laboratory, Winston-Sa]em, N.C.
} 
Table 1. Characteristics of experimental clgarettes *.

\begin{tabular}{|c|c|c|c|c|c|}
\hline Tobacco type & $\begin{array}{c}\text { Leaf } \\
\text { position }\end{array}$ & $\begin{array}{l}\text { Weight } \\
\text { (mg) }\end{array}$ & $\begin{array}{l}\text { Moisture } \\
(\%)\end{array}$ & $\begin{array}{l}\text { Draw resistance } \\
\left(\mathrm{mm} \mathrm{H}_{2} \mathrm{O}\right)\end{array}$ & $\begin{array}{c}\text { Static burning rate } \\
\text { (mg/min) }\end{array}$ \\
\hline \multirow[t]{8}{*}{ Burley: Burley 21} & 1 & 841 & 10.0 & 78 & 66.8 \\
\hline & 2 & 880 & 9.8 & 80 & 65.6 \\
\hline & 3 & 853 & 9.9 & 58 & 61.4 \\
\hline & 4 & 856 & 9.5 & 64 & 61.4 \\
\hline & 5 & 810 & 9.5 & 55 & 55.2 \\
\hline & 6 & 854 & 10.0 & 57 & 52.8 \\
\hline & 7 & 831 & 10.0 & 45 & 54.5 \\
\hline & 8 & 805 & 9.0 & 40 & 51.0 \\
\hline \multirow{8}{*}{$\begin{array}{r}\text { Burley: Burley } 21, \\
\text { low-alkaloid }\end{array}$} & 1 & 851 & 10.5 & 91 & 69.0 \\
\hline & 2 & 872 & 11.8 & 80 & 66.7 \\
\hline & 3 & 803 & 10.9 & 63 & 65.6 \\
\hline & 4 & 805 & 10.9 & 56 & 60.2 \\
\hline & 5 & 835 & 11.5 & 51 & 60.9 \\
\hline & 6 & 859 & 10.5 & 55 & 57.4 \\
\hline & 7 & 812 & 10.3 & 45 & 58.9 \\
\hline & 8 & 851 & 10.3 & 48 & 56.9 \\
\hline \multirow[t]{8}{*}{ Burley: Ky 12} & 1 & 847 & 10.0 & 75 & 61.9 \\
\hline & 2 & 856 & 10.0 & 62 & 63.2 \\
\hline & 3 & 847 & 11.0 & 59 & 61.1 \\
\hline & 4 & 819 & 12.0 & 54 & 57.4 \\
\hline & 5 & 825 & 12.5 & 55 & 58.2 \\
\hline & 6 & 885 & 11.5 & 51 & 48.4 \\
\hline & 7 & 811 & 12.5 & 38 & 51.5 \\
\hline & 8 & 849 & 10.0 & . 42 & 49.2 \\
\hline \multirow[t]{8}{*}{ Burley: Ky 14} & 1 & 839 & 12.0 & 84 & 65.2 \\
\hline & 2 & 848 & 11.5 & 66 & 68.3 \\
\hline & 3 & 854 & 10.9 & 60 & 59.0 \\
\hline & 4 & 822 & 12.0 & 52 & 57.8 \\
\hline & 5 & 868 & 12.1 & 61 & 54.9 \\
\hline & 6 & 851 & 12.4 & 46 & 55.8 \\
\hline & 7 & 815 & 11.9 & 42 & 54.6 \\
\hline & 8 & 876 & 13.0 & 45 & 47.8 \\
\hline
\end{tabular}

* $85 \mathrm{~mm}$, non-filter

smoke analyses were conducted at the American Health Foundation. Analytical procedures have been reported previously (12). Table 1 presents the average values for the cigarettes studied.

\section{EXPERIMENTAL VARIABLES}

A total of 116 variables were included in this study. Different methods were used by different laboratories for some of these variables.

Leaf Variables: stalk position, moisture, sand, ash, alkalinity of water-soluble ash, $\mathrm{Ca}, \mathrm{K}, \mathrm{Mg}, \mathrm{Mn}, \mathrm{Cl}$, reducing sugar, starch, holocellulose, malic acid, oxalic acid, citric acid, nicotine, nornicotine, myosmine, anabasine, anatabine, total alkaloids, total volatile bases, ammonia, $\alpha$-amino nitrogen, nitrate, total nitrogen, petroleum ether extract, wax, oven volatiles, phytosterols, total carbonyls, chlorogenic acid, rutin, total polyphenols, and neophytadiene.

Cigarette Variables: moisture, weight, draw resistance, static burning rate, nicotine content, and puff numbers.

Smoke Delivery and Smoke Component Variables: Total particulate matter (TPM), nicotine, water, phenol, o-cresol, $m$-cresol, $p$-cresol, $m$-ethylphenol, $p$-ethylphenol, 
2,3- and 2,5-dimethylphenol, smoke ammonia, hydrogen cyanide (HCN) in gas phase, hydrogen cyanide in particulate phase, pyridine, 2-ethylpyridine, 3-ethylpyridine, 2,3-lutidine, 2,4-lutidine, 2,5-lutidine, 2,6-lutidine, 3,4lutidine, and 2,4,6-collidine, $\beta$ - and $\gamma$-picoline, catechol, benzo[a]pyrene, acetaldehyde, acrolein, isoprene, acetonitrile, $\mathrm{CO}, \mathrm{CO}_{2}, \mathrm{~N}$-nitrosodimethylamine (NDMA), $N$-nitrosoethylmethylamine (NEMA), $N$-nitrosopyrrolidine, $N^{\prime}$-nitrosoanatabine (NA'T), $N^{\prime}$-nitrosonornicotine (NNN), 4-(methylnitrosamino)-1-(3-pyridyl)-1-butanone (NNK), total non-volatile amines, $\mathrm{NO}$, smoke $\mathrm{pH}$ at puff numbers 3,5 , and 7 .

\section{RESULTS AND DISCUSSION}

The analytical data for the above-mentioned variables were examined statistically. We found significant differences among the four cultivars as well as among stalk positions. Simple correlations and multiple regressions are also calculated. The results are as follows:

\section{A. Major Difference Among Cultivars}

Burley 21: The following variables are significantly higher in this cultivar than in the others studied: moisture, oxalic acid, nicotine, total alkaloids, total volatile bases, ammonia, nitrate, total nitrogen and oven volatiles in leaf; nicotine in condensate; and picolines, NAT, $\mathrm{NNN}$, and total non-volatile amines in smoke.

Low-Alkaloid Burley 21: The following variables are significantly higher in this cultivar than in the three other Burley cultivars tested: ash, $\mathrm{Ca}, \mathrm{K}$, malic acid, petroleum ether extract, phytosterols in leaf; and 3,4lutidine in smoke.

$K y$ 12: The following variables are significantly higher in this cultivar than in the other cultivars: $\mathrm{Mg}$, citric acid- $\alpha$-amino nitrogen, total phenols and neophytadiene in leaf; and TPM, hydrogen cyanide, 3-ethylpyridine, acetaldehyde, acrolein, isoprene, acetonitrile in smoke, and $\mathrm{pH}$ of smoke.

Ky 14: The following variables are significantly higher in this cultivar than in other cultivars studied: sand, chloride, total carbonyls in leaf; dry condensate; NNN, water and pyridine in smoke.

\section{B. Major Differences in Stalk Position}

Data from all cultivars of the same stalk position are combined for this study.

1. The following variables decrease from bottom to top leaf positions (bottom leaves have higher values): ash, alkalinity of water-soluble ash, $\mathrm{Ca}, \mathrm{K}$, citric acid, nitrate, petroleum ether extracts, wax, phytosterols, total carbonyls, draw resistance and static burning rate of the experimental cigarettes; and acetaldehyde and acrolein in the smoke of these cigarettes. The decrease in draw resistance and the decrease in burning rate with ascend- ing stalk position have also been observed for bright tobacco varieties (12). These correlations can be explained by the increased density of the cured leaves from upper stalk positions.

2. The following variables increase from bottom to top leaf positions (bottom leaves have lower values): nicotine, total alkaloids, total volatile bases, $\alpha$-amino nitrogen, total nitrogen of the experimental cigarettes; and TPM, water in TPM, phenol, ammonia, hydrogen cyanide, pyridine, picoline, lutidine, catedhol, isoprene, carbon monoxide, NDMA and NEMA in the smoke of these cigarettes as well as smoke $\mathrm{pH}$.

3. Other variables do not have a definite pattern of distribution in their amounts relative to stalk position.

4. The relationships of certain compounds or factors to stalk positions are shown in Figures 1 through 12 with all four cultivars, as follows:

Figure 1: draw resistance vs. stalk position.

Figure 2: neophytadiene vs. stalk position.

Figure 3: smoke $\mathrm{pH}$ vs. stalk position (Burley 21).

Figure 4: smoke pH vs. stalk position (low-alkaloid Burley 21).

Figure 5: smoke $\mathrm{pH}$ vs. stalk position (Burley, Ky 12).

Figure 6: smoke $\mathrm{pH}$ vs. stalk position (Burley, Ky 14).

Figure 7: catedol vs. stalk position.

Figure 8: acetaldehyde in smoke.

Figure 9: acrolein in smoke.

Figure 10: acetonitrile in smoke.

Figure 11: isoprene in smoke.

Figure 12: $N$-nitrosopyrrolidine in smoke.

\section{Simple Correlations among Selected Leaf and Smoke Variables}

Some simple correlations among selected leaf and smoke variables are listed in Table 2 . These data are in agreement with our previous findings in bright tobaccos (12). The most important factors associated with the levels of many undesirable smoke components (13) appear to be nitrogenous factors other than nitrate and completeness of combustion. For example, variables such as FTC* condensate (- TPM minus nicotine and water), smoke nicotine, total non-volatile amines, total volatile phenols, hydrogen cyanide, benzo[a]pyrene, catechol, smoke $\mathrm{pH}$, and carbon monoxide are negatively correlated with potassium and nitrate contents, which are known to increase the static burning rate, and are positively correlated with total nitrogen, total alkaloids, total volatile bases, a-amino nitrogen, and ammonia, which reflect organic fractions inhibiting completeness of combustion. One interesting phenomenon is that three smoke com-

Federal Trade Commission 


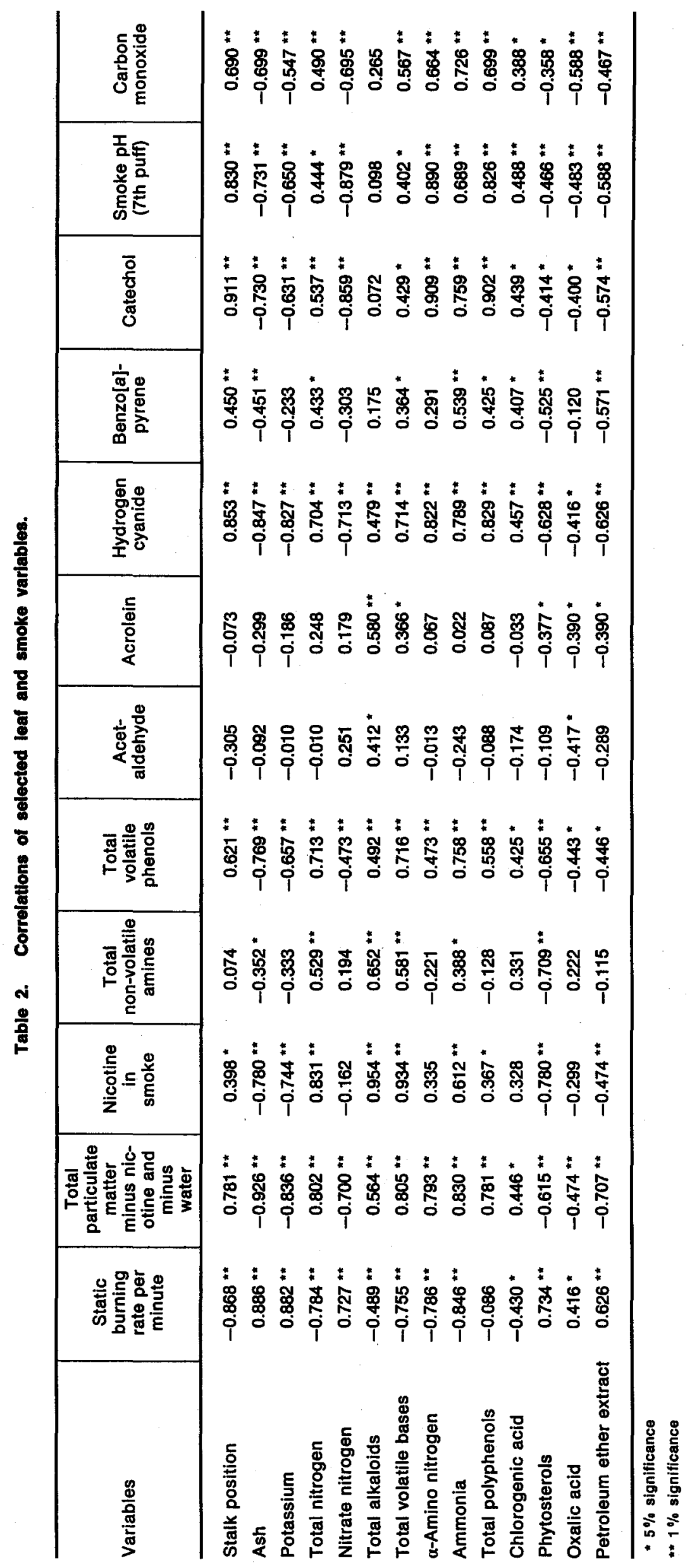


Figure 1. Draw resiatance vs. stalk position.

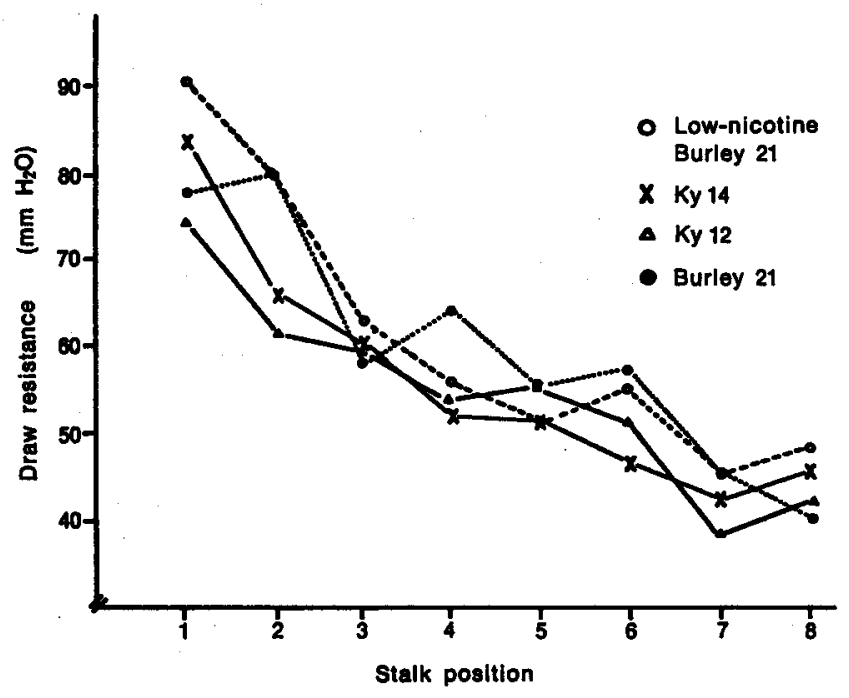

Figure 2. Neophytadiene vs. stalk position.

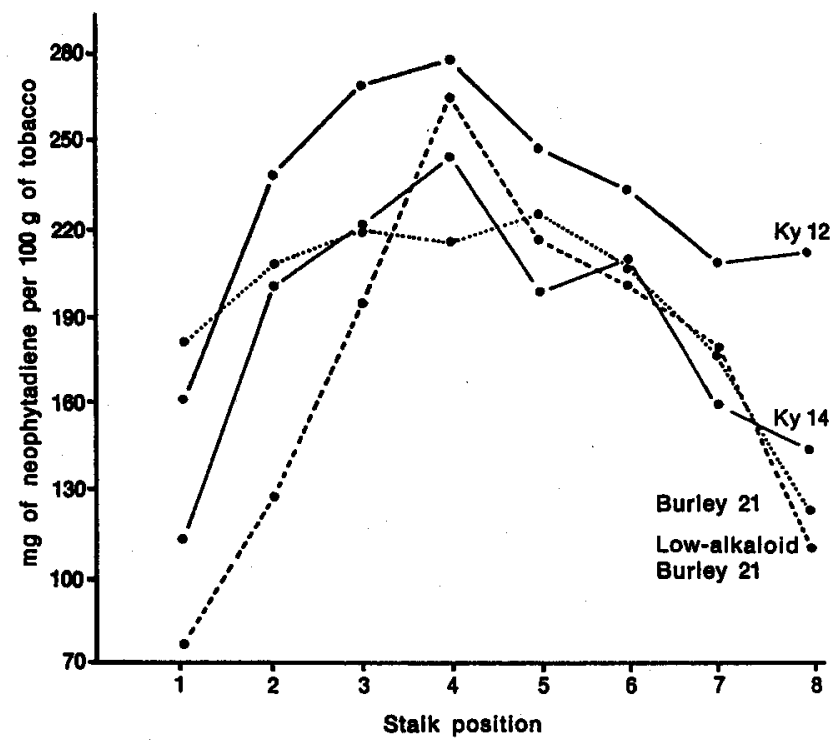

Figure 3. Smoke pH ve. stalk position (Burley, Burley 21).

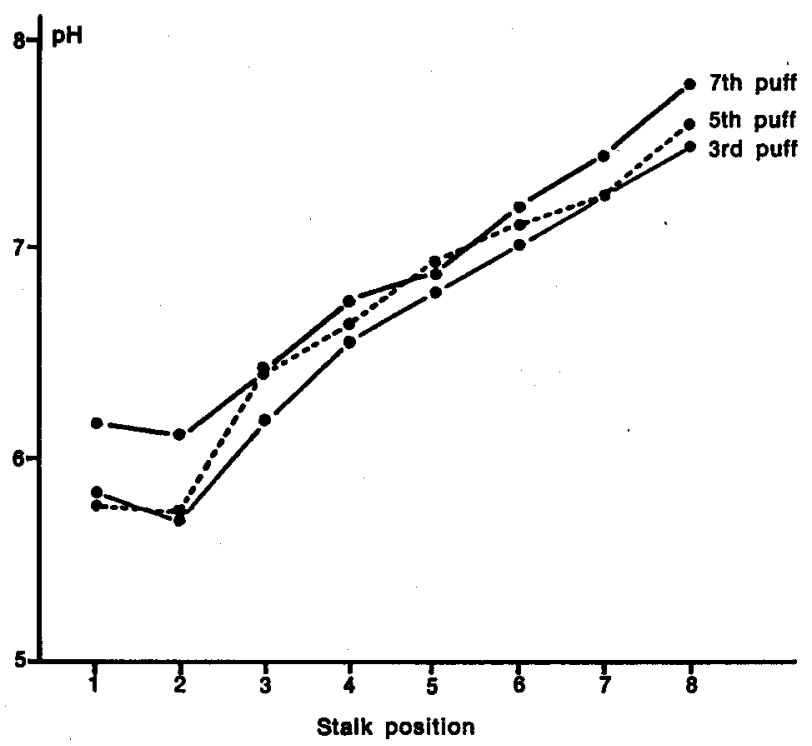

Figure 4. Smoke pH ve. stalk position (Burley, low-al-
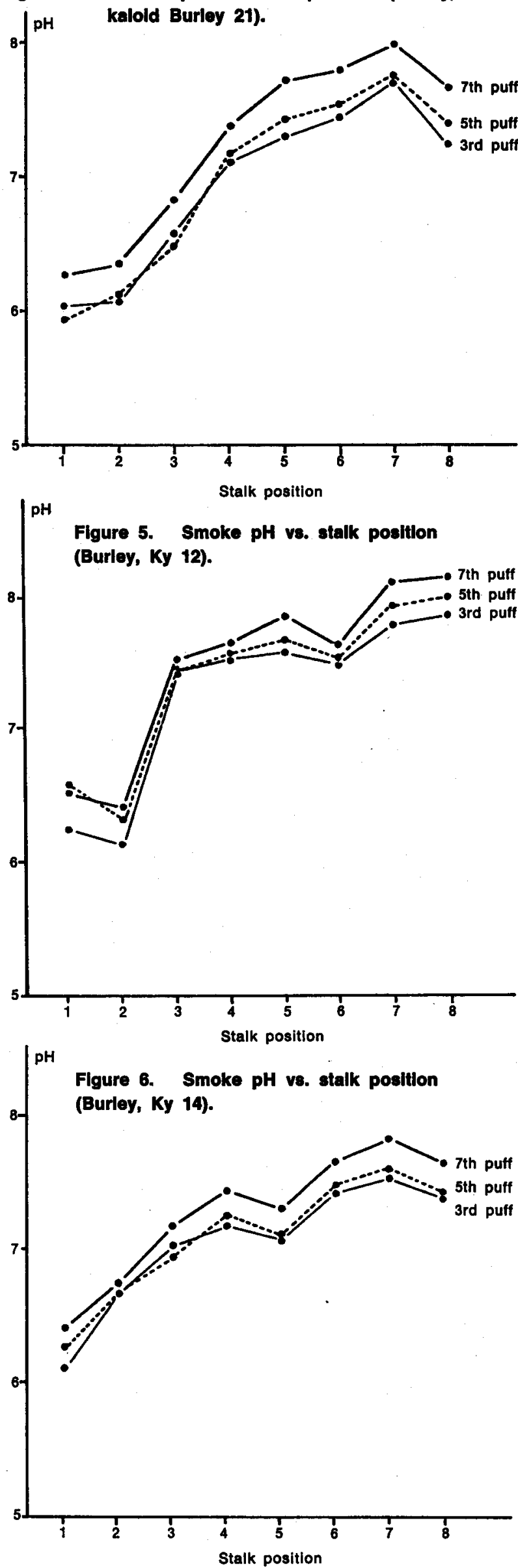


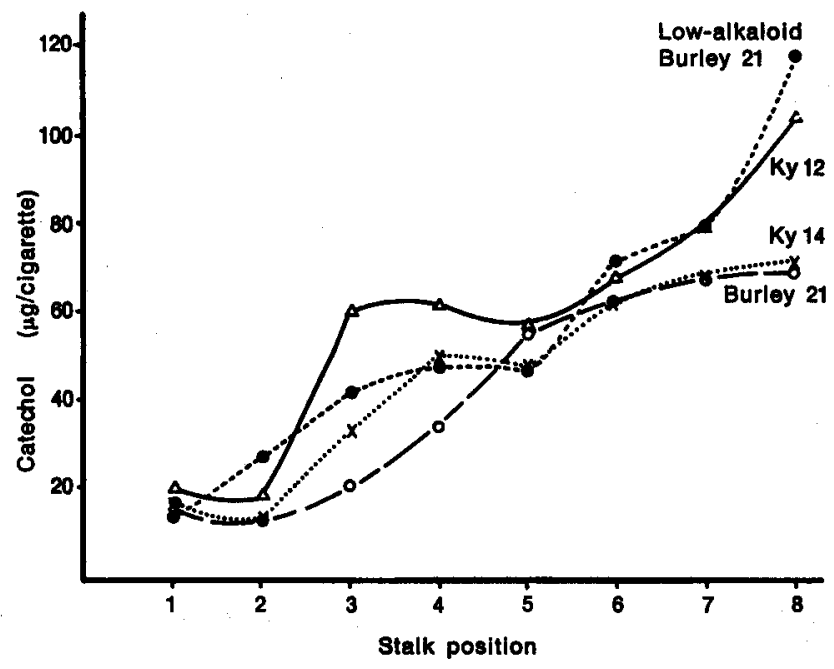

Flgure 8. Acetaldehyde in smoke.

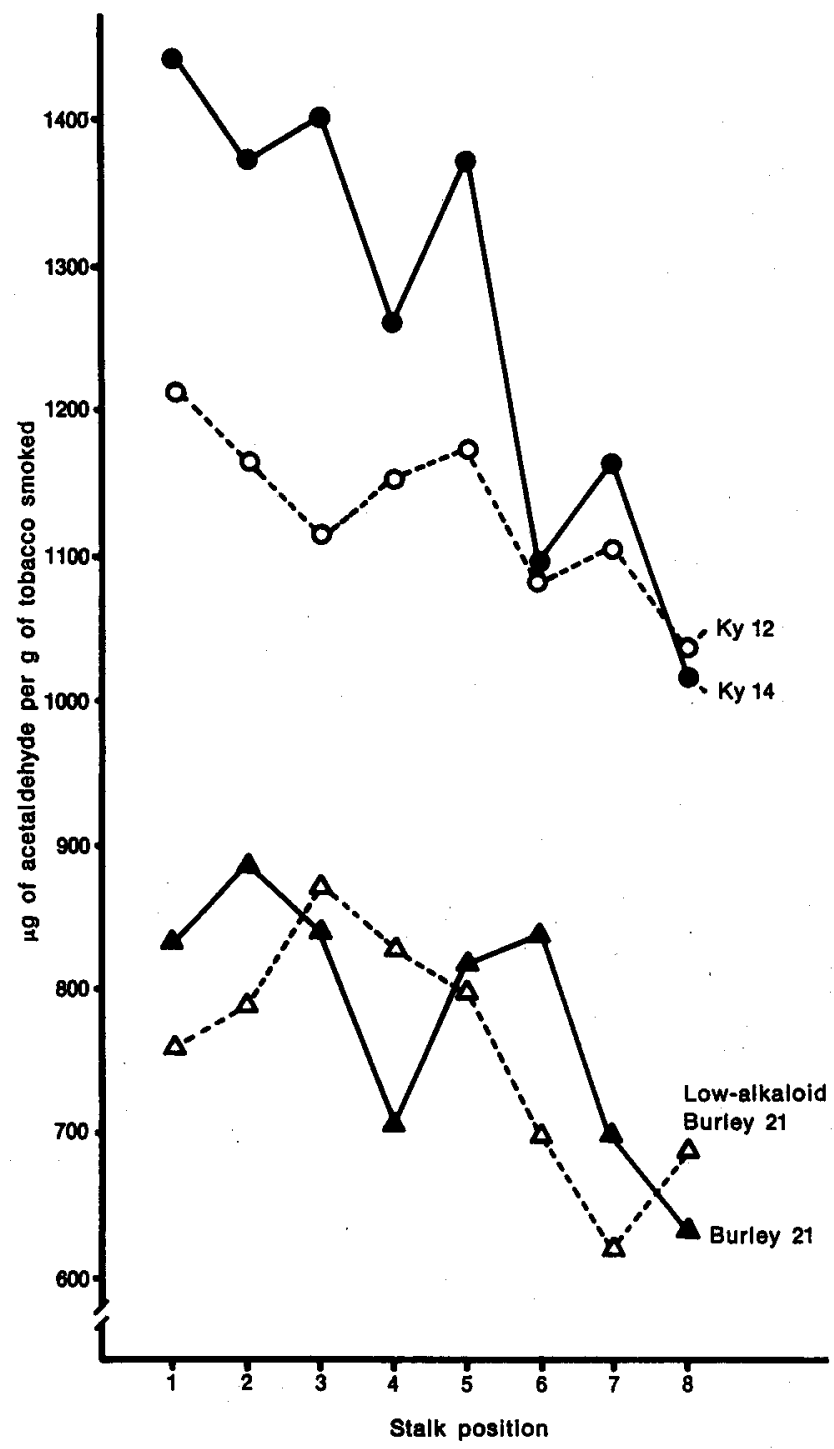

ponents - hydrogen cyanide, catechol, and carbon monoxide - appeared to be positively correlated with leaf variables, even though their respective precursors and pathways of formation are most likely quite different.

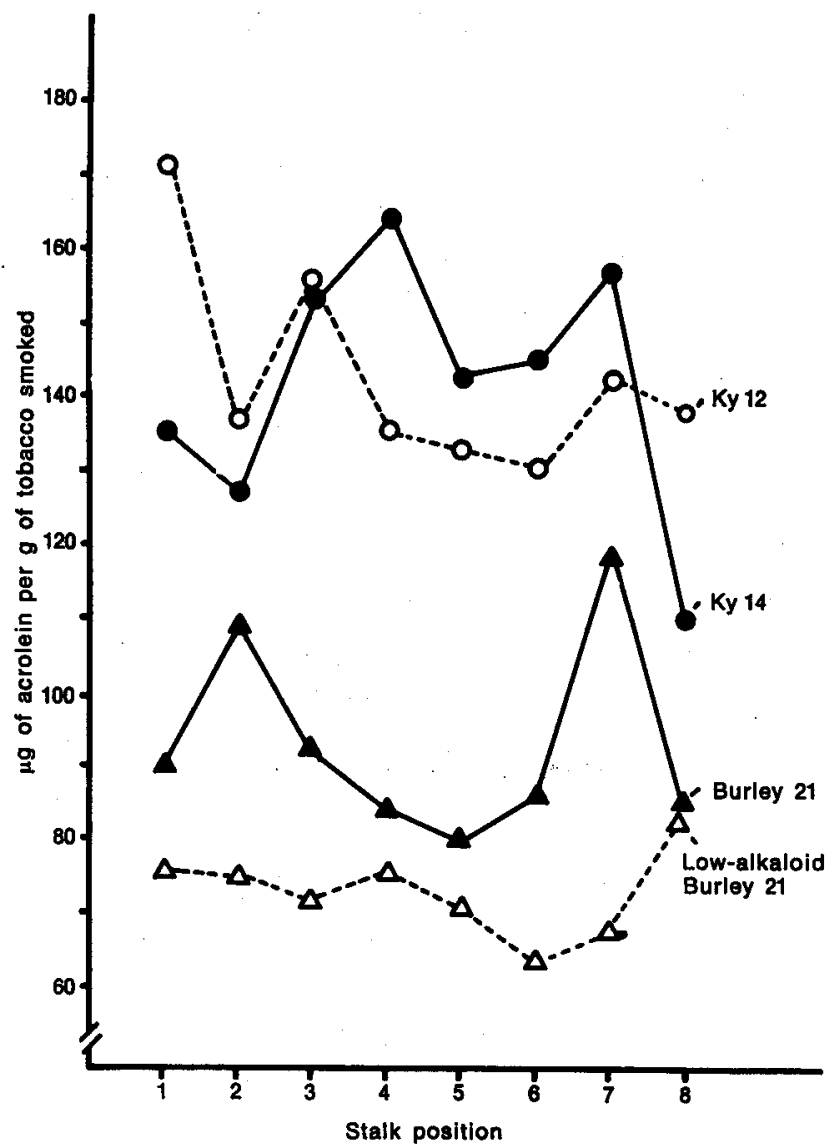

\section{Multiple Regressions}

We have, on the basis of the simple correlation data, selected several important variables for computation of multiple regression. Using this concept, one can predict the level of certain smoke components when a few leaf variables are known.

1. Total particulate matter (TPM) minus nicotine and water (FTC condensate): This variable is highly correlated with ash, reducing sugar, oxalic acid, total volatile bases, total nitrogen, phytosterols, polyphenol and burning rate.

a. When only ash and total volatile bases (TVB) are used, estimated FTC condensate (mg/cigarette) = $54.375-1.5462 \times$ ash $(\%)-1.8175 \times$ TVB $(\%)$, and $R^{2}=0.8607$.

b. When ash, phytosterols and total nitrogen are used, estimated FTC condensate (mg/cigarette) $=19.6908$ $-1.500 \times$ ash $(\%)+3.592 \times$ total nitrogen $(\%)+$ $7.519 \times$ phytosterols $(\mathrm{mg} / \mathrm{g})$, and $\mathrm{R}^{2}=0.9094$.

The study supports our earlier finding with bright tobacco cultivars (12) in that the combustibility of the cigarette filler determines the FTC condensate yield.

2. Benzo[a]pyrene (ng/cig.): In this study, this variable is correlated with ash, petroleum ether extract, wax, 


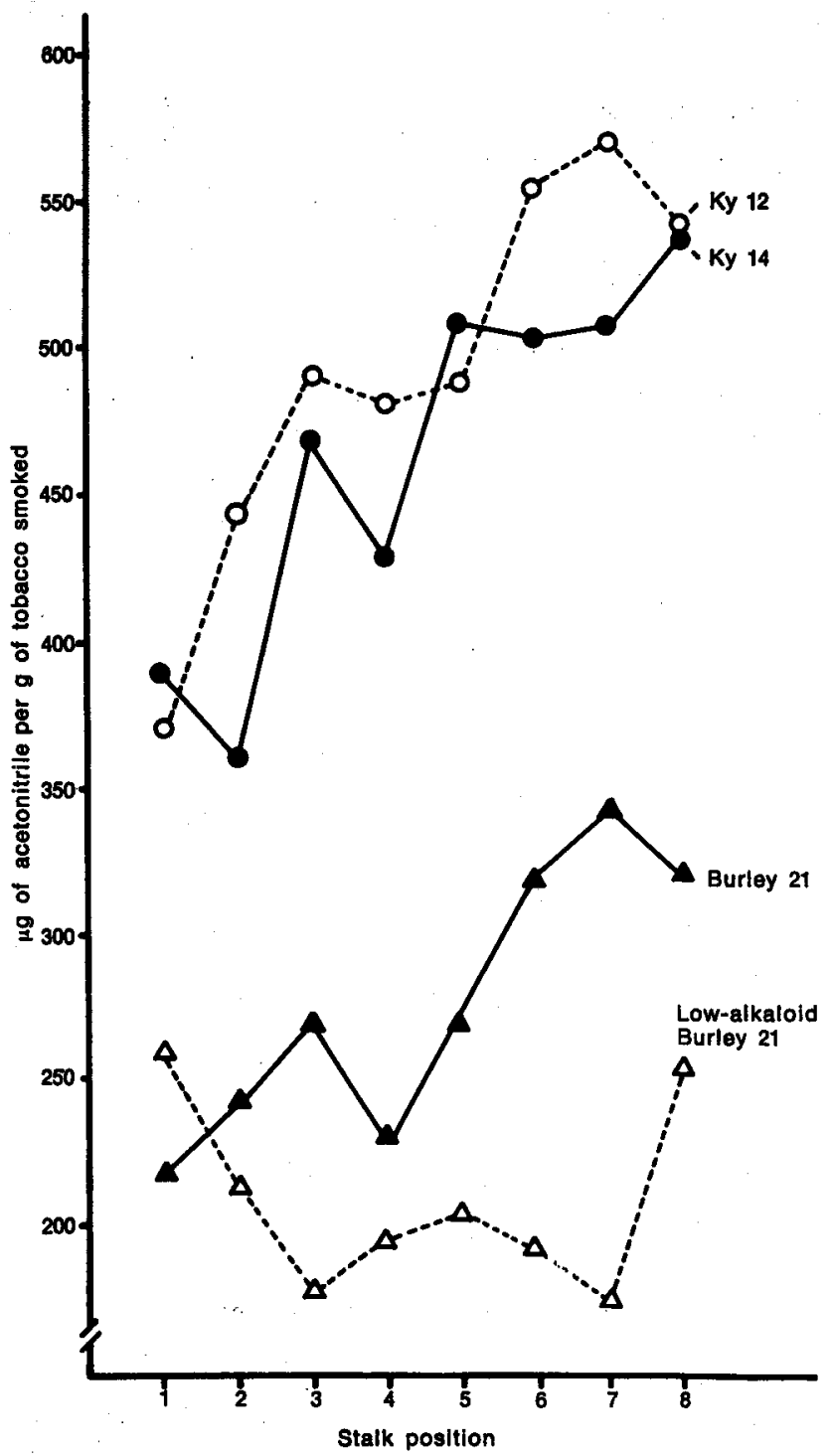

phytosterols and others, but the correlation values are not high, although they show statistical significance.

a. When only petroleum ether extract and phytosterols are used, estimated B [a]P (ng/cigarette) $=78.6657-$ $6.7889 \times$ petroleum ether extract $(\%)-12.2124 \times$ phytosterols $(\mathrm{mg} / \mathrm{g})$, and $\mathrm{R}^{2}=0.3916$.

b. When petroleum ether extract, phytosterols, and wax are used, estimated benzo[ $a]$ pyrene (ng/cigarette) $=$ $83.9363-6.2217 \times$ petroleum ether extract $(0 / 0)-$ $23.0863 \times$ wax $(\%)-9.5141 \times$ phytosterols $(\mathrm{mg} / \mathrm{g})$, and $\mathrm{R}^{2}=0.4220$.

This study confirms an observation made by us, and by others (4), in respect to the bright tobacco cultivars (12), namely that the petroleum-ether extractable "waxy" layer of the leaf has a great influence on $B[a] P$ yields in the smoke.

3. Total bydrogen cyanide ( $\mu$ g/cig.): The hydrogen cyanide in smoke correlates with ash, potassium, total ni-

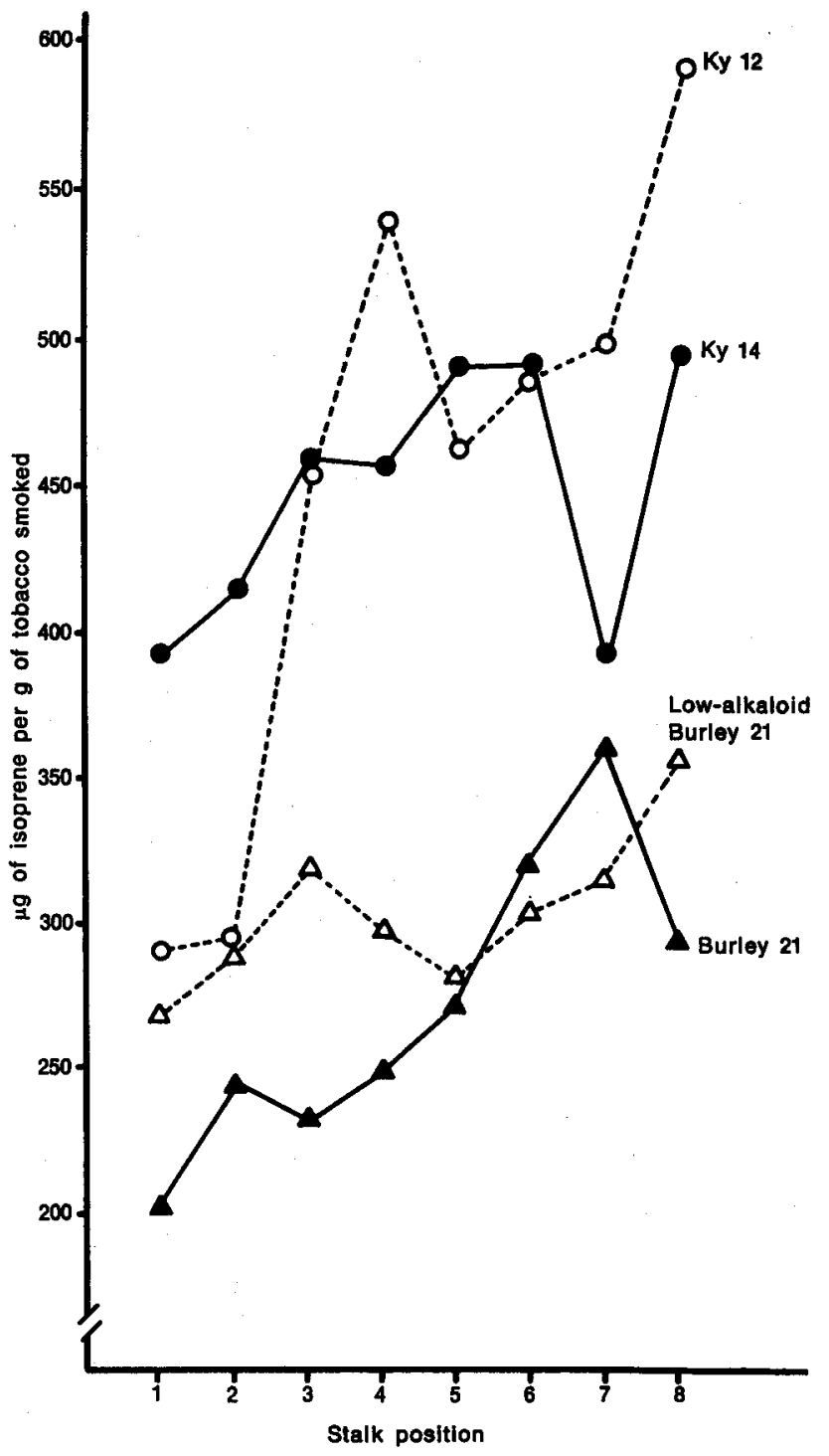

trogen, nitrate nitrogen, $\alpha$-amino nitrogen, alkaloids, polyphenols, and other variables.

a. When only ash and polyphenols are used, estimated hydrogen cyanide $(\mu \mathrm{g} / \mathrm{cig})=.774.1951-26.0529 \times$ ash $(\%)+47.9472 \times$ total polyphenols $(\mathrm{mg} / \mathrm{g})$, and $\mathrm{R}^{2}=0.7983$.

b. When ash, polyphenol, and nicotine in smoke are used, estimated hydrogen cyanide $(\mu \mathrm{g} /$ cigarette) $=$ $320.6694-9.6564 \times$ ash $(\%)+30.9836 \times$ nicotine in smoke $(\mathrm{mg} / \mathrm{cig}$. $)+63.9221 \times$ total polyphenols $(\mathrm{mg} / \mathrm{g})$, and $\mathrm{R}^{2}=0.8176$.

c. When $\alpha$-amino nitrogen, ash, and phytosterols are used, estimated hydrogen cyanide ( $\mu \mathrm{g} /$ cigarette) $=$ $685.8327+493.8399 \times \alpha$-amino nitrogen $(\%)-$ $12.6318 \times$ ash $(\%)-118.3110 \times$ phytosterols $(\mathrm{mg} / \mathrm{g})$ and $\mathrm{R}^{2}=0.8068$.

This observation is in line with the model studies by Jobnson and Kang on the hydrogen cyanide pyrosynthesis from amino acids and proteins during tobacco 
Figure 12. N-Nitrosopyrrolldine In smoke.

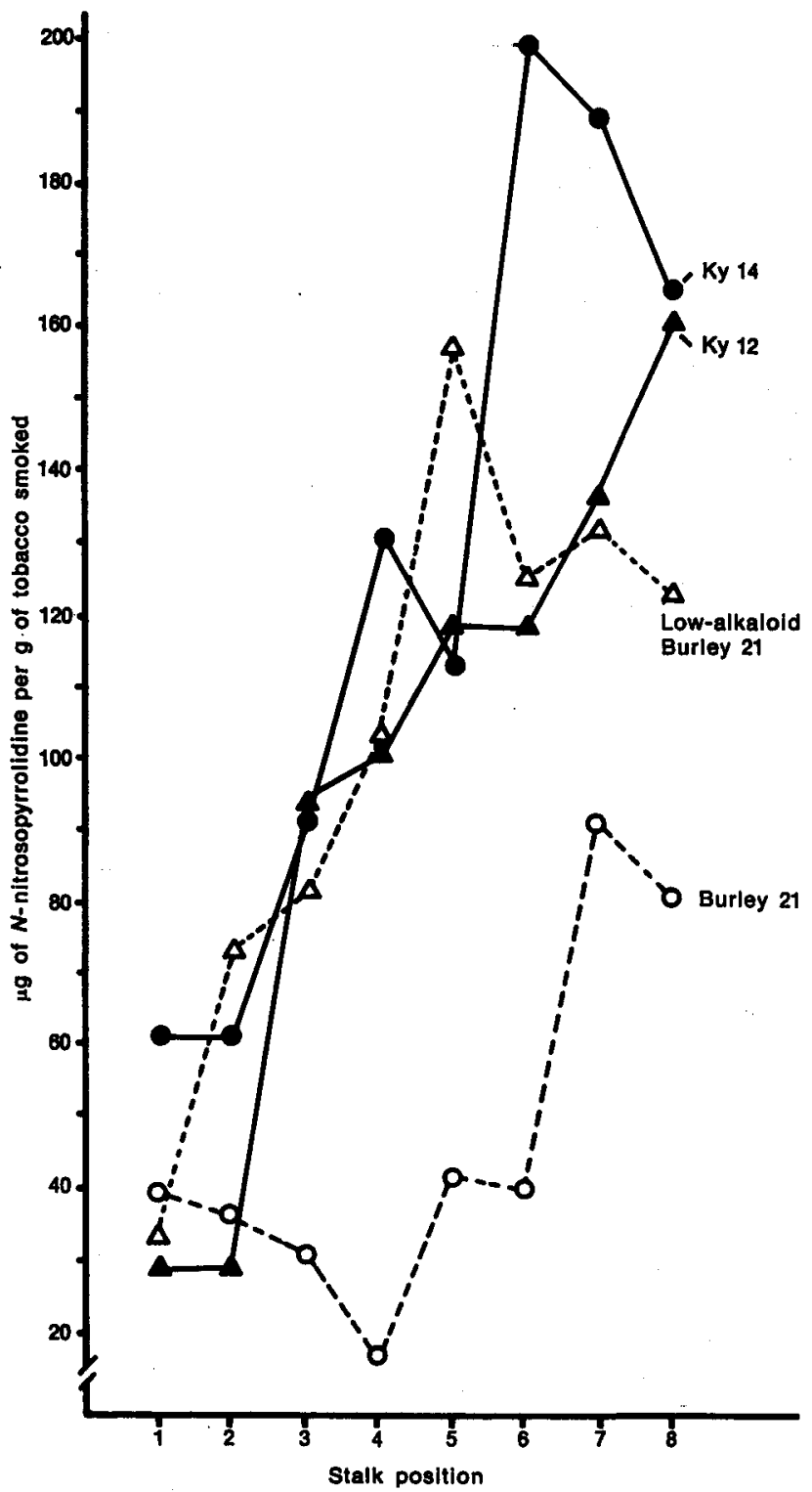

smoking (7). In our earlier study with bright tobacco cultivars the correlation factor between hydrogen cyanide and $\alpha$-amino nitrogen was 0.569 and between hydrogen cyanide and total nitrogen 0.831 (12). This too supports the Jobnson and Kang concept (7).

4. Acrolein ( $\mu \mathrm{g} / \mathrm{g}$ tobacco smoked): Acrolein is correlated with malic acid, citric acid, moisture content, chloride, and nicotine in leaf tobacco.

a. When malic acid and moisture are used, estimated arolein $(\mu \mathrm{g} / \mathrm{g})=49.9759-39.069 \times$ malic acid $(\%)$ $+13.5148 \times$ moisture $(\%)$, and $R^{2}=0.5594$.

b. When malic acid, citric acid, and moisture are used, estimated acrolein $(\mu \mathrm{g} / \mathrm{g})=-16.3676-31.4384 \times$ malic acid $(\%)+12.4679 \times$ citric acid $(\%)+$ $13.7433 \times$ moisture $(\%)$, and $\mathrm{R}^{2}=0.6341$.

c. When chloride, malic acid, citric acid, nicotine, and moisture are used, estimated acrolein $(\mu \mathrm{g} / \mathrm{g})=$ $-100.0071+26.0323 \times$ chloride $(\%)-11.7307$ $\times$ malic acid $(\%)+13.2836 \times$ citric acid $(\%)+$ $8.6185 \times$ nicotine $(\%)+10.3582 \times$ moisture $(\%)$, and $R^{2}=0.6954$.

These data from the four Burley cultivars and our earlier data from bright cultivars have not indicated the chemical nature of a possible precursor for acrolein in cigarette smoke.

5. Smoke phenol ( $\mu \mathrm{g} / \mathrm{cig}$.): Total smoke phenols are correlated with the static burning rate, total volatile bases, total polyphenols, phytosterols, and other variables.

When the static burning rate and total volatile bases are used, estimated smoke phenols ( $\mu \mathrm{g} / \mathrm{cigarette})=$ $168.8201+45.3035 \times$ total volatile bases $(\%)-$ $1.9427 \times$ static burning rate $(\mathrm{mg} / \mathrm{min})$, and $\mathrm{R}^{2}=$ 0.6145 .

This finding supports earlier model studies which suggest that polyphenols are major precursors for smoke phenols (14).

6. Carbon monoxide (mg/cig.): $\mathrm{CO}$ ist correlated with ash, $\mathrm{Mn}$, oxalic acid, $\alpha$-amino nitrogen, nitrate nitrogen, stalk position of leaf and other variables.

a. When ash, $\mathrm{Mn}$, and oxalic acid are used, estimated $\mathrm{CO}$ $(\mathrm{mg} / \mathrm{cig})=.40.0311-0.3729 \times$ ash $(\%)-67.2779$ $\times \mathrm{Mn}(\%)-2.3940 \times$ oxalic acid $(\%)$, and $\mathrm{R}^{2}=$ 0.6151 .

b. When ash, Mn, oxalic acid, and leaf position are used, estimated carbon monoxide (mg/cig.) $=33.4874-$ $0.07125 \times$ ash $(\%)-44.7216 \times \mathrm{Mn}(\%)-3.2048$ $\times$ oxalic acid $(\%)+0.3371 \times$ leaf position on stalk, and $\mathbf{R}^{2}=0.6568$.

c. When $\mathrm{Mn}$, oxalic acid, $\alpha$-amino nitrogen, and leaf position are used, estimated carbon monoxide $(\mathrm{mg} / \mathrm{cig})=.37.7078-45.3088 \times \mathrm{Mn}(\%)-4.4486$ $\times$ oxalic acid $(\%)-5.7303 \times \alpha$-amino nitrogen $(\%)+0.6035 \times$ leaf position, and $\mathrm{R}^{2}=0.6743$.

d. When ash and nitrate nitrogen are used, estimated carbon monoxide (mg/cig.) $=32.5305-0.3970 \times$ ash $(\%)-3.5566 \times$ nitrate nitrogen $(\%)$, and $R^{2}$ $=0.5787$.

This study strongly indicates that the carbon monoxide yield in smoke increases with the ascending stalk position of the Burley leaf from which it derives. As discussed earlier, the upper leaves have a lower free burning rate and lower nitrate content than the leaves from lower stalk positions. It was also demonstrated earlier that increased nitrate levels accelerate combustibility of tobacco leaves (9).

7. Catechol $(\mu \mathrm{g} / \mathrm{cig}$.$) : Catechol is correlated with leaf$ positions, total polyphenols, $\alpha$-amino nitrogen, nitrate nitrogen, ash, and other variables.

a. When $\alpha$-amino nitrogen, total polyphenols, and leaf positions are used, estimated catechol $(\mu \mathrm{g} /$ cigarette $)=$ 
$-42.6052+67.9408 \times \alpha$-amino nitrogen $(\%)+$ $8.1022 \times$ total polyphenols $(\mathrm{mg} / \mathrm{g})+4.8229 \times$ leaf position, and $R^{2}=0.9033$.

b. When ash, $\alpha$-amino nitrogen, total polyphenols, and leaf positions are used, estimated catechol ( $\mu \mathrm{g} / \mathrm{cig}$.) $=$ $-97.6975+2.1940 \times$ ash $(\%)+70.9869 \times$ $\alpha$-amino nitrogen $(\%)+8.9664 \times$ total polyphenols $(\mathrm{mg} / \mathrm{g})+5.9924 \times$ leaf position, and $\mathrm{R}^{2}=0.9119$.

c. When a-amino nitrogen, nitrate nitrogen, and polyphenols are used, estimated catechol ( $\mu \mathrm{g} /$ cigarette) $=$ - $29.4526+89.3271 \times \alpha$-amino nitrogen $(\%)$ $-19.5463 \times$ nitrate nitrogen $(\%)+11.8454 \times$ total polyphenols $(\mathrm{mg} / \mathrm{g})$, and $\mathrm{R}^{2}=0.8701$.

This study strongly supports model experiments which indicate that polyphenols are major precursors for catechol in the smoke (5).

8. $N^{\prime}-N i t r o s o n o r n i c o t i n e ~ o r ~ N N N ~(\mu \mathrm{g} / \mathrm{g})$ : Although nicotine and nornicotine serve as precursors for this nitrosamine (6), NNN in smoke is also correlated with oven volatiles, phytosterols, rutin, and other variables.

a. When oven volatiles and phytosterols are used, estimated NNN $(\mu \mathrm{g} / \mathrm{g})=20.0553+5.03130 \times$ oven volatiles $(\%)-18.8373 \times$ phytosterols $(\mathrm{mg} / \mathrm{g})$, and $\mathbf{R}^{2}=0.7419$.

b. When oven volatiles, phytosterols and rutin are used, estimated $\mathrm{NNN}(\mu \mathrm{g} / \mathrm{g})=25.3531+4.3506 \times$ oven volatiles $(\%)-19.2959 \times$ phytosterols $(\mathrm{mg} / \mathrm{g})-$ $6.5542 \times$ rutin $(\%)$, and $R^{2}=0.7487$.

9. Nicotine in smoke can be estimated with known values of total nitrogen (including leaf nicotine and nitrate nitrogen) and phytosterols, as follows:

Nicotine in smoke $(\mathrm{mg} / \mathrm{g})=95.5874+4.8476 \times$ total nitrogen $(\%)-51.5518 \times$ phytosterols $(\mathrm{mg} / \mathrm{g})$, and $R^{2}=0.7216$.

This correlation indicates that the transfer rate of nicotine from the tobacco into the mainstream smoke, which varies between $15 \%$ and $20 \%$ in the U.S. blended cigarette (10), is greatly influenced by total nitrogen and phytosterols of the leaf. The latter are correlated with the combustibility of the leaf (12).

10. Total non-volatile amines in smoke can be estimated with known values of total alkaloids, total volatile bases, and phytosterols, as follows:

Total non-volatiles amines $(\mu \mathrm{g} / \mathrm{g}$ tobacco burned) $=$ $87.1998+6.4616 \times$ total alkaloids $(\%)-40.4355$ $X$ total volatile bases $(\%)-32.3161$ phytosterols $(\mathrm{mg} / \mathrm{g})$, and $\mathrm{R}^{2}=0.6729$.

11. Smoke $p H$ can be estimated with ash, nitrate nitrogen, and a-amino nitrogen. We selected puff \#7 and calculated as follows:

Smoke pH (puff \#7) $=8.4124-0.0563 \times$ ash $(\%)+2.1786 \times$ nitrate nitrogen $(\%)-1.2900 \times$ $a$-amino nitrogen $(\%)$, and $R^{2}=0.8440$.
This observation supports the concept that nitrate in tobacco is a main precursor for ammonia in the smoke (8) and, thus, for smoke $\mathrm{pH}(2,8)$.

\section{E. Nicotine-Free Dry TPM (TPM - nicotine - water $=$ FTC condensate) and Benzola/pyrene Deliver- ies of Four Burley Tobaccos}

Of the four entries of Burley tobacco tested in this experiment, LA Burley 21 has the lowest nicotine level $(0.86 \%), \mathrm{Ky} 14(3.71 \%)$ and $\mathrm{Ky} 12(3.66 \%)$ have intermediate levels, and Burley 21 the highest nicotine level $(4.20 \%)$. However, the nicotine-free dry TPM delivery of the experimental cigarettes made from these tobaccos does not follow the nicotine patterns. Ky 14 has a significantly higher TPM delivery than the others, Burley 21 is second, and Ky 12 and LA Burley are the lowest, with no significant differences between them.

The means of the benzo[a]pyrene deliveries of the four entries are not statistically different, although Ky 14 had a higher value, compared with the rest. The means from these eight leaf positions also show no significant differences, although leaves from the upper stalk positions deliver a higher benzo[a]pyrene level than do those from the lower positions, an observation also made for bright tobacco cultivars.

\section{SUMMARY}

Leaves from 8 stalk positions from four Burley tobaccos, the cultivars Burley 21, Ky 14 and $\mathrm{Ky} 12$ and one breeding line of low-alkaloid Burley 21 (LA Burley 21), were tested in this study. A total of 116 variables, including leaf and smoke characteristics, were determined by collaborating scientists using established methods. Simple correlations and multiple regressions among selected variables were determined to examine the relationship among these variables. Generally, Burley tobaccos do not differ from bright tobaccos, in that the nitrogenous fractions and combustibility appear to be the major factors affecting nicotine and dry TPM (total particulate matter) delivery as well as other major smoke constituents. Stalk position and varieties also demonstrated significant differences in nicotine and dry TPM delivery. Benzo $[a]$ pyrene content, however, did not show significant differences among these experimental Burley tobaccos or stalk positions.

\section{ZUSAMMENFASSUNG}

Bei vier Burley-Tabaken (Burley 21, Kentucky 14, Kentucky 12 und eine Zuchtlinie des Burley 21 mit geringem Alkaloidgehalt (LA Burley 21)) wurde das Blattgut differenziert nach acht Positionen an der Sproßachse untersucht. Insgesamt wurden 116 Variable zur Blatt- und Rauchbeschaffenheit von Wissenschaftlern verschiedener Laboratorien unter Benutzung anerkannter Methoden 
bestimmt. Zur Untersuchung der zwischen diesen Variablen bestehenden Beziehungen wurden $z$ wischen ausgewähiten Variablen einfache Korrelationen und multiple Regressionen bestimmt. Zwischen den Burley-Tabaken und hellen Tabaken zeigte sich insofern kein Unterschied, als die Ausbeute an Nikotin und Kondensat (Partikelphase ohne Nikotin und Wasser) und auch an anderen widhtigen Rauchinhaltsstoffen vor allem von der Stickstofffraktion und den Brenneigenschaften des Tabaks bestimmt wird. Die Unterschiede im Nikotin- und Kondensatgehalt wurden signifikant von der Blattposition und der Tabaksorte bestimmt. Für den Gehalt an Benzo[a]pyren waren solche Unterschiede nicht $z u$ beobachten.

\section{RESUME}

Dans le cadre de cette étude, on a distingué huit étages foliaires pour quatre tabacs Burley (Burley 21, Kentucky 14, Kentudky 12 et une variété de culture du Burley 21 à faible teneur en alcaloïde (LA Burley 21)). Des chercheurs de divers laboratoires, ayant appliqué des méthodes reconnues, ont déterminé les valeurs de 116 variables compte tenu des caractéristiques de la feuille et de la fumée. Afin d'établir les relations existant entre ces variables, on a déterminé des corrélations simples et des régressions multiples entre certaines variables hoisies. Aucune différence n'a été décelée entre les tabacs Burley et les tabacs blonds, dans la mesure où ce sont surtout les fractions azote et la combustibilité du tabac qui exercent la plus grande influence sur la teneur en nicotine et en condensat (phase-particules sans nicotine ni eau), ainsi que sur d'autres importants constituants de la fumée. L'étage foliaire et la variété de tabac constituent des facteurs déterminants en ce qui concerne la teneur en nicotine et en condensat; par contre, on ne peut observer de telles différences pour ce qui est de la teneur en benzo[a]pyrère.

\section{REFERENCES}

1. Baker, R. R.: Mechanisms of smoke formation and delivery; Recent Advan. Tobacco Sci. 6 (1980) 184-224.

2. Brunnemann, K. D., and D. Hoffmann: Chemical studies on tobacco smoke, XXXIV. Gas chromatographic determination of ammonia in cigarette and cigar smoke; J. Chromatogr. Sci. 13 (1975) 159-163.

3. Gori, G. B. (editor): Toward less hazardous cigarettes - The third set of experimentai cigarettes; U.S. Dept. Health, Education and Welfare Publ. No. (NIH) 77-1280, 1977, pp. 152.

4. Gori, G. B. (editor): 'Toward less hazardous cigarettes - The fourth set of experimental cigarettes; U.S. Dept. Health, Education and Welfare Publ., March 1980, pp. 213.

5. Hecht, S. S., S. Carmella and D. Hoffmann: Chemical studies on tobacco smoke, LXX: Quantitative analysis of alkyl-2-hydroxy-2-cyclopenten-1-ones in tobacco smoke; J. Agr. Food Chem. 29 (1981) 401404.

6. Hoffmann, D., G. Rathkamp and Y. Y. Liu: Chemical studies on tobacco smoke, XXVI. On the isolation and identification of volatile and non-rolatile $\mathrm{N}$-nitrosamines and hydrazines in cigarette smoke; Intern. Agency Res. Cancer Sci. Publ. 9 '(1974) 159-164.

7. Johnson, W. R., and J. C. Kang: Mechanisms of hydrogen cyanide formation from the pyrolysis of amino acids and related compounds; J. Org. Chem. 36 (1971) 189-192.

8. Johnson, W. R., R. W. Hale, S. C. Clough and P. $H$. Chen: Chemistry of the conversion of nitrogen nitrate to smoke products; Nature 243 (1973) 223225.

9. Rathkamp, G., and D. Hoffmann: Chemical studies on tobacco smoke, XIII. Inhibition of the pyrosynthesis of several selective smoke constituents; Beitr. Tabakforsch. 5 (1970) 302-306.

10. Schmeltz, I., A. Wenger, D. Hoffmann and T. C. Tso: Chemical studies on tobacco smoke, LXIII. On the fate of nicotine during pyrolysis and in a burning cigarette; J. Agr. Food Chem. 27 (1979) 602608.

11. Tso, T. C.: Physiology and biochemistry of tobacco plants; Dowden, Hutchinson and Rosss, Inc., Stroudsburg, PA, 1972, pp. 393.

12. Tso, T. C., and J. F. Chaplin: Simple correlation and multiple regression among leaf characteristics, smoke components, and biological responses of bright tobaccos; U.S. Dept. Agric. Techn. Bull. 1551, 1977, pp. 135.

13. U.S. Department of Health and Human Services: The changing cigarette; Dept. Health Human Serv. (PHS) 81-50156, 1981, pp. 135.

14. Wynder, E. L., and D. Hoffmann: Tobacco and tobacco smoke; Academic Press, New York, N.Y., 1967, pp. 730.

Addresses of autbors:

T. C. Tso,

Tobacco Laboratory,

Beltsville Agricultural Research Center,

Agricultural Research Service,

U.S. Department of Agriculture,

Beltsville, Maryland, 20705, U.S.A.

J.F. Chaplin,

Oxford Tobacco Station,

Agricultural Research Service,

U.S. Department of Agriculture,

Oxford, N.C., 27565 U.S.A.

J.D. Adams and D. Hoffmann,

Naylor Dana Institute for Disease Prevention,

American Health Foundation,

Valhalla, New York, 10595, U.S.A. 